\title{
Design and Analysis of Band Notched Wide Band Metamaterial Integrated U \& T Shaped Patch with Strip Line Antenna for Wireless Application
}

\author{
${ }^{1}$ Rani Rudrama Kodali, ${ }^{2}$ P. Siddaiah, ${ }^{3}$ Dr. M. N. Giri Prasad \\ ${ }^{1}$ Dept. of Electronics and Communication Engineering, JNTU-Anantapuram, India; \\ 2, University College of Engineering \& Technology, ANU, Gunturu,India; \\ ${ }^{3}$ JNTU-Anantapur College of Engineering,ndiaEngineering, Anantapuram, India; \\ Kodali.rudrama@gmail.com
}

Received: 06th October 2017 Accepted: 14th November 2017, Published: 31st December 2017

\begin{abstract}
In this paper, we design a metamaterial based antenna for wideband applications. For the design we consider a unit cell of MM by integrating a $U$ shape patch section with $\mathrm{T}$ shape patch, Three such unit cells were attached together to form the desired wideband antenna. Here the dielectric substrate used is Rogers RT/duroid 5880 ${ }^{\mathrm{TM}}$.Initially we analyze the proposed antenna and then we will analyze the effects of proposed cases on the designed wideband MM antenna. The proposed cases for the analysis purpose are, first we consider the ground conditions by analyzing the designed antenna with full ground, half ground and the proposed ground conditions. second by increasing its feeding strip line width by a change of $0.05 \mathrm{~cm}$, $0.1 \mathrm{~cm}$ and $0.15 \mathrm{~cm}$ in $-X$ and $+X$ directions at $M M$ side and then for the third case increasing the feeding strip line width at port side in the same manner. The comparative analysis is presented by analyzing the proposed wideband MM antenna for all these for various conditions with the help of return loss $\left(\mathrm{S}_{11}\right)$ and VSWR curves.
\end{abstract}

Keywords: Metamaterial, Negative Refractive Index, Micro Strip Patch Antenna, Wideband.

\section{Introduction}

Antennas have fundamental importance in wireless communications, with the increase in demand and advance in wireless broad band technologies. The need for antennas with greater bandwidth is high, because of their low cost, simple structure and good wide impedance and pattern bandwidth, the ultra-wideband antennas have become main research topic for several researchers[1-2]. The frequency range from $3.1 \mathrm{GHz}-10.6 \mathrm{GHz}$ are used for commercial UWB applications, however some existing WLAN bands and some satellite services which are working at 8 to $11 \mathrm{GHz}$ may cause some intrusion. While working on UWB antennas the main requirement is that it requires convenient

impedance matching over large bandwidth, and the miniaturization of the antenna and higher radiation efficiency [3] is required. This UWB technologies have several advantages over the conventional antenna systems, one such advantage is that it does not require any carrier frequency instead the UWB antennas emits timed pulse of electromagnetic energy. Overview of some planar wideband antennas with different configurations is presented in [5]. Here the intrusion between the UWB and already existing systems using some of the frequency bands is one of the key problems in working with the UWB antennas to avoid such interference we must avoid those frequencies from the UWB antenna band this is achieved by using band notch method, some researches on UWB antennas with band notch characteristics is presented in [4,6-9].

\section{The Existing and proposed work}

To achieve the band notched characteristics various techniques have been proposed and researched in that embedding slots or slits in the radiating patch or on the ground is one [6-9]. In recent times using metamaterial based parasitic elements, SRR, EBG also delivered promising results in achieving the band notched UWB antennas. These are only good with single band notched UWB but some time dual or multi band notching is required, so the multi band notched UWB antenna is proposed [10]. But the main disadvantage in working with dual/multiband notched UWB antenna is mutual coupling and leakage due to slots/slits on patch. The use of negative index metamaterial based SRR UWB antenna has given improved performance [12]. In our present work we propose negative index based MM antenna to have multi band notch characteristics with improved performance. The proposed MM based UWB antenna have band at 5$7.5 \mathrm{GHz}$ frequency range and at some other bands over the frequency range 5 to $20 \mathrm{GHz}$. The bands which are to be notched can be tuned by variations considered in this paper.

\section{Design of Metamaterial and Its Unit cell}

\subsection{Metamaterial Structure}

Our initial goal is to have unit cell layout which have resonance property that covers the operating frequency range $5 \mathrm{GHz}$ to $20 \mathrm{GHz}$ range. Here the metamaterial unit cell is prepared by integrating a $\mathrm{U}$ shape patch with $\mathrm{T}$ shaped section along with strip connection. The figure [1] depicts the dimensions of the designed unit cell. 


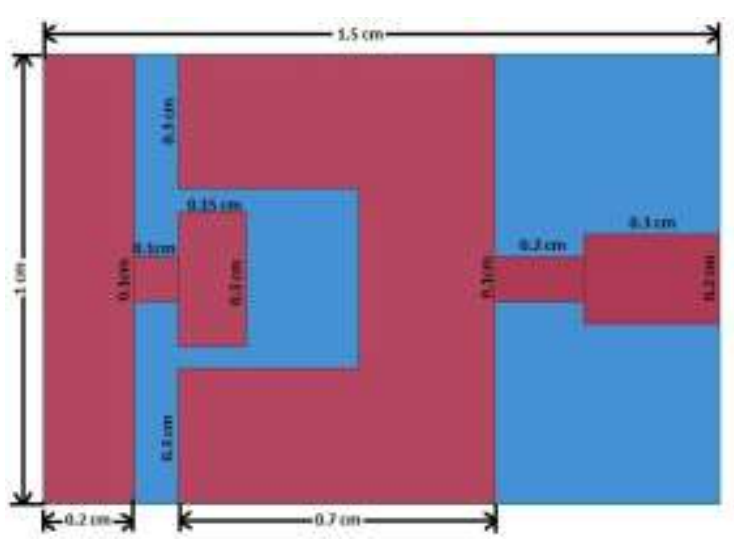

Figure [1] Proposed Unit Cell Design

Now the proposed unit cell is printed on Rogers RT/ Duroid 5880 ${ }^{\mathrm{TM}}$ dielectric substrate having dimensions $1 \mathrm{~cm} \times 1.5 \mathrm{~cm} \times 62 \mathrm{mil}$ in $\mathrm{x}, \mathrm{y} \& \mathrm{z}$ directions. And it is placed inside a air box for applying boundary conditions and the unit cell setup for analysis is shown in the following figure [2].

The negative values of the permeability and permittivity will be calculated by the following equations.The Nicolson Rose Weir (NRW) method was used to find the effective relative permittivity $\left(\varepsilon_{\mathrm{r}}{ }^{\text {eff }}\right)$, permeability $\left(\mu_{\mathrm{r}}^{\text {eff }}\right.$ ) and refractive index $\left(\mathrm{n}^{\mathrm{eff}}\right)$. In order to find the effective values from the transmission and reflection data the unit cell dimensions must be very small than the operating wave length in the media. At the interface between the dielectric slab (thickness $d=62$ mil in this case) and free space, the reflection coefficient can be expressed as follows:

$$
\Gamma=\frac{Z_{0}-1}{Z_{o}+1}
$$

Where $Z_{o}$ is the relative impedance in terms of $\mu, \mathcal{E}$.

$$
Z_{0}=\sqrt{\mu_{r} / \varepsilon_{r}}
$$

The transmission coefficient $\mathrm{Z}$ can be expressed as

$$
Z=\exp \left(-j(w / c) \sqrt{\mu_{r} \varepsilon_{r} d}\right)
$$

By the above three equations the transmission and reflection parameters can be obtained by the following equations

$$
\begin{aligned}
& S_{21}=\frac{\left(1-\Gamma^{2}\right) Z}{1-\Gamma^{2} Z^{2}} \\
& S_{11}=\frac{\left(1-Z^{2}\right) \Gamma}{1-\Gamma^{2} Z^{2}}
\end{aligned}
$$

Where the transmission coefficient is expressed as $Z=\exp \left(-j(w / c) \sqrt{\mu_{r} \varepsilon_{r} d}\right.$, where $\mathrm{c}$ is the velocity of light. And $\mathrm{w}=2 \pi \mathrm{f}$ is the angular frequency. Using similar approach to eq(1) the following equations can be written as

$$
\begin{gathered}
\mu_{r}=\frac{2 c\left(1-S_{21}+S_{11}\right)}{j w d\left(1+S_{21}-S_{11}\right)} \\
\varepsilon_{r}=\mu_{r}+j \frac{2 c S_{11}}{w d} \\
n_{r}=\sqrt{\mu_{r} \varepsilon_{r}}
\end{gathered}
$$

The scattering parameters were calculated using HFSS the perfect electric and magnetic conditions were imposed on air box for the analysis purpose the unit cell is placed in it with two ports top and bottom side a uniform plane wave is propagated through Z-axis when excited. The orientation of the unit cell design is clearly presented in the following figure [2].

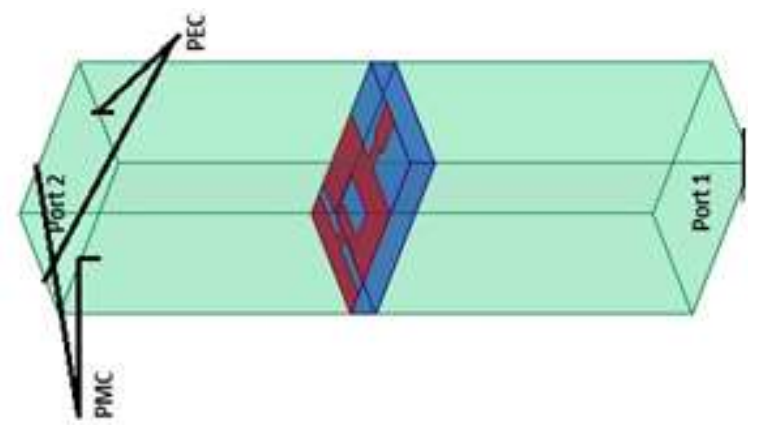

Figure [2] Unit Cell Setup for Analysis

Now after analyzing the above setup shown in the figure [2] using HFSS we can get the transmission and reflection characteristics by $S_{21}$ and $S_{11}$ curves shown in the following figure [3].



Figure [3] Simulated results of S- Parameter for unit cell shown in figure[2].

In the above figure [3] the transmission $\left(S_{11}\right)$ peaks occurs at 9.1, 9.9, 11.1, 12.45, 14.62, 15.32, 17.96, \& $19.49 \mathrm{GHz}$, indicating the left handed band from self resonance, overlap and the larger overlap currents with respect to existing MM designs it is 
clear that the magnetic response of the proposed $\mathrm{MM}$ is good.

\subsection{The Proposed Wideband MM antenna}

Now, the proposed Wideband MM antenna is designed by three elements of MM unit cells and it is represented in figure [4].

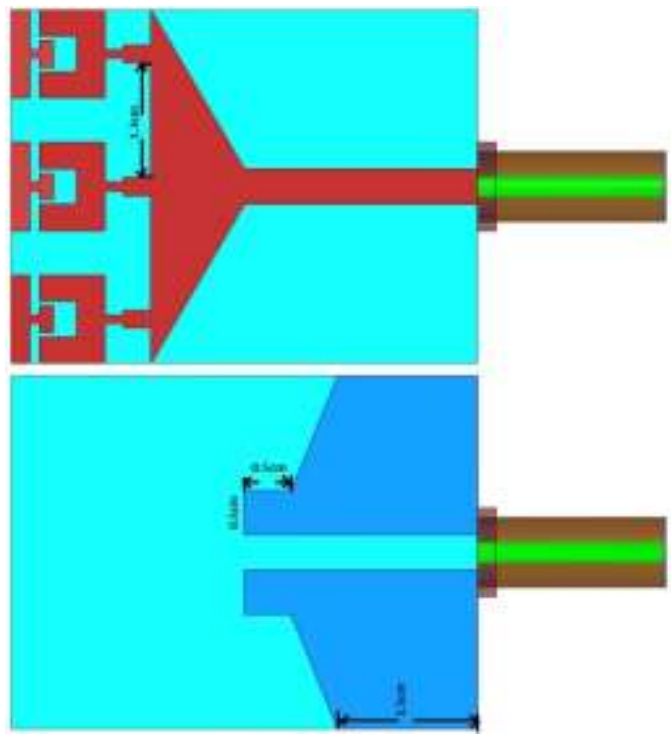

Figure [4] the proposed three element wideband MM antenna a) Top View b) Bottom view

\subsection{The Proposed Wideband MM antenna Return $\operatorname{loss}\left(S_{11}\right)$ and VSWR curves}

The proposed antenna is designed and analyzed using the Ansys HFSS software the return loss and the VSWR curve for the proposed antenna or shown in the following figures [5] \& [6].

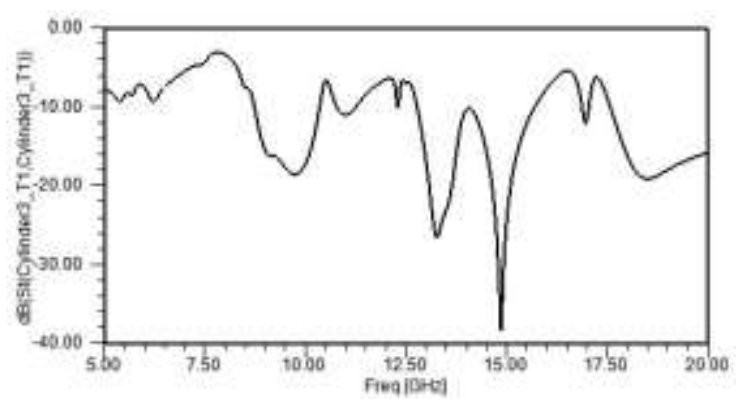

Figure [5] The return loss curve for the proposed wideband MM antenna

In the above figure [5] we can see that there are few frequency bands that have band width more than the $500 \mathrm{MHz}$ band width requirement of wideband applications. So the proposed antenna works better in case of wideband applications.

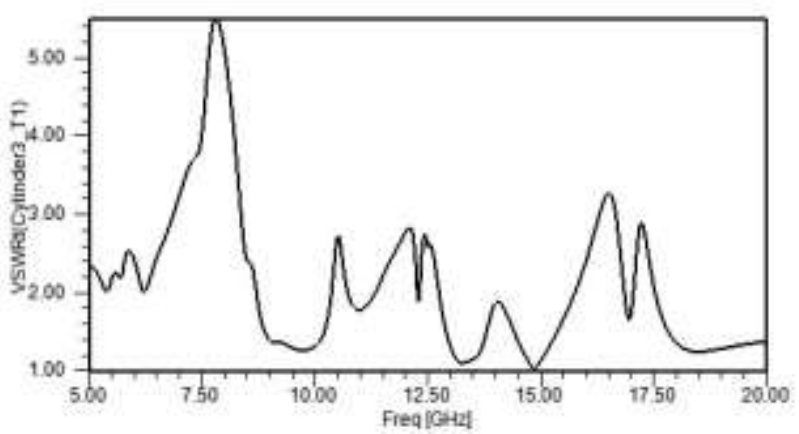

Figure [6] The VSWR curve for the proposed wideband MM antenna

The VSWR curve indicates how well the antenna radiates, even though VSWR data is alone is not enough to determine whether the antenna radiates properly or not it can still explains if the antenna is properly tuned in quick manner. Lower the VSWR the better the antenna can radiate the received power. In the figure [3] as we can see the resonance occurred around after the $7.5 \mathrm{GHz}$ range here in the above figure [6] we can clearly understand that the VSWR is below three at frequency $>7.5 \mathrm{GHz}$.

\section{Different cases considered for the analysis of proposed wideband MM antenna}

For the analysis purpose we consider some cases to determine how the proposed antenna bandwidth ranges and VSWR are affected.

\subsection{The ground conditions}

We consider the full ground, half ground and proposed grounds to find the variations in BW and VSWR. The ground conditions are shown in the following figure [7].



Figure [7] Ground conditions a) Full ground b) Half ground c) Proposed ground

\subsection{Feed strip line variation at MM antenna side}

The feed strip line is varied in the MM Unit side by adding $\Delta \mathrm{x}=0.05 \mathrm{~cm}$ variation to the strip line along $-\mathrm{X}$ and $+\mathrm{X}$ direction in the following figure [8]. The strip line has $0.4 \mathrm{~cm}$ width now a change of $\Delta \mathrm{x}=0.05,0.1, \quad 0.15 \mathrm{~cm}$ are considered for the analysis purpose to determine effect on $\mathrm{BW}$ changes and VSWR. 


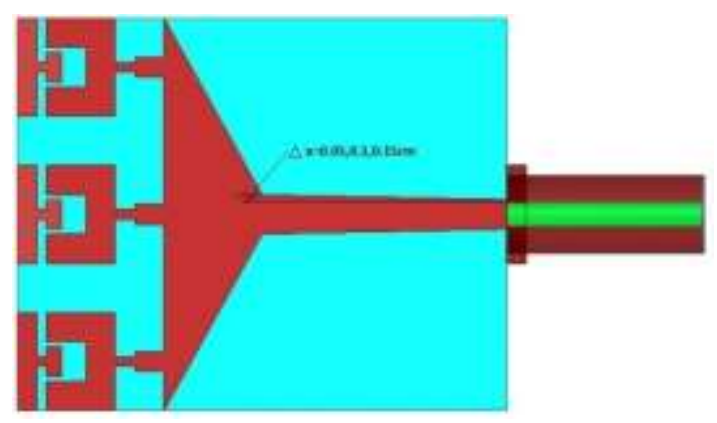

Figure [8] Feeding strip line variation at MM side.

\subsection{Feed strip line variation at Port side}

The feed strip line is varied at port by adding $\Delta \mathrm{x}=0.05 \mathrm{~cm}$ variation to the strip line along $-\mathrm{X}$ and $+X$ direction in the following figure [9]. The strip line has $0.4 \mathrm{~cm}$ width now a change of $\Delta \mathrm{x}=0.05,0.1$, $0.15 \mathrm{~cm}$ are considered for the analysis purpose to determine effect on BW changes and VSWR.

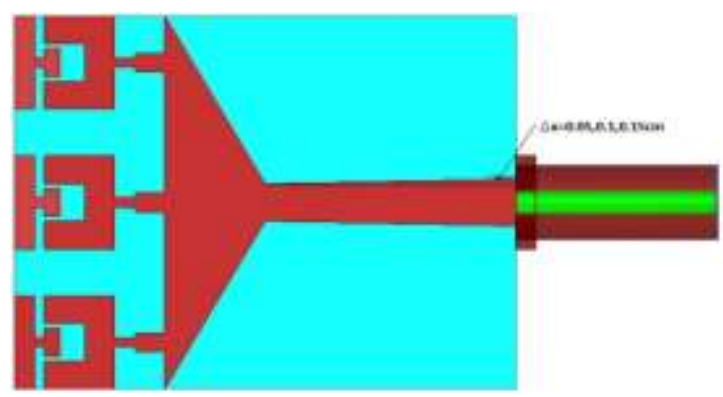

Figure [9] Feeding strip line variation at Port side.

\section{Comparative analysis}

Now for all the three cases mentioned in the above section the changes are analyzed and the comparative analysis using return loss and VSWR curves are shown in the following figures [10] \& [11].

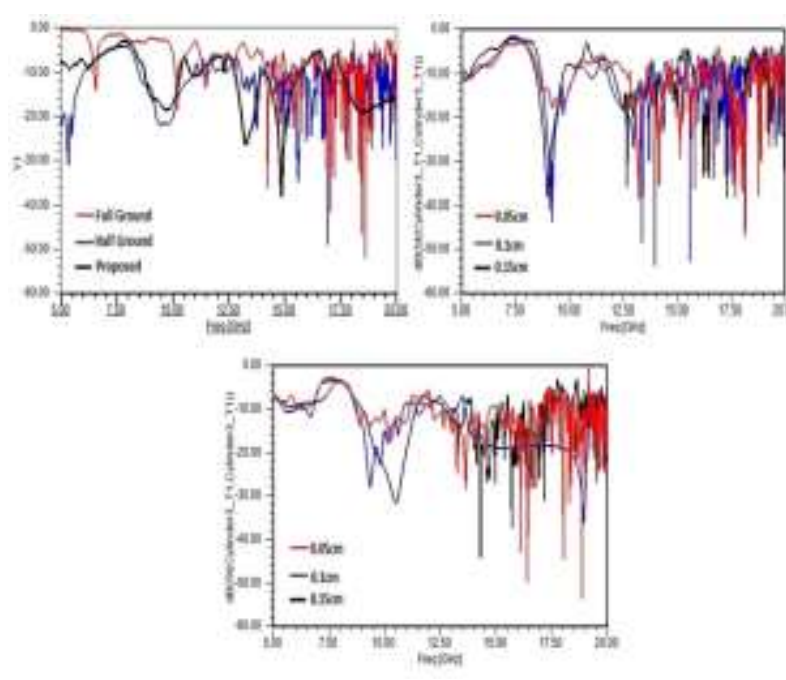

Figure [10] Return loss curve comparison a) Full ground, half ground \& proposed ground b) Feeding Strip line variation at MM units side for 0.05, 0.1, $\& 0.15 \mathrm{~cm}$ changes. c) Feeding Strip line variation at port side for $0.05,0.1, \& 0.15 \mathrm{~cm}$ changes.
In the above figure [10] we can see that how the considered conditions affect the antenna operating Band widths the variations clearly indicated in the Table [1].

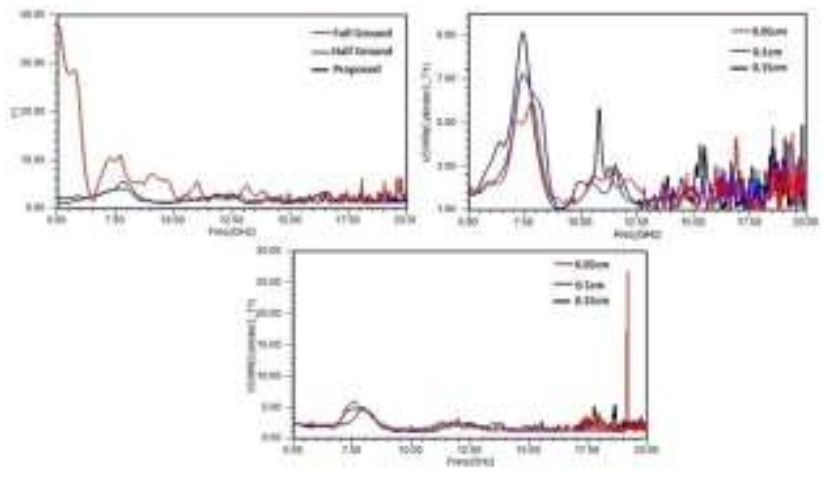

Figure [11] VSWR curve comparison a) Full ground, Half ground \& proposed ground b) Feeding Strip line variation at MM units side for 0.05, 0.1, $\& 0.15 \mathrm{~cm}$ changes. c) Feeding Strip line variation at port side for $0.05,0.1, \& 0.15 \mathrm{~cm}$ changes.

In the above figure [11] a we can see that VSWR is good for proposed ground and the half ground conditions than the full ground conditions. Similarly when feed strip line is increased by $0.05 \mathrm{~cm}, 0.1 \mathrm{~cm}$ and $0.15 \mathrm{~cm}$ in $-X$ and $+X$ directions VSWR is good for $0.05 \mathrm{~cm}$ and $0.1 \mathrm{~cm}$ variations. And for feed strip line variations at port side almost three variations have good VSWR.

Table 1. Band width above 500Mhz regions for all variations

\begin{tabular}{|c|c|c|}
\hline S.No & conditions & Band width Ranges \\
\hline 1 & Full Ground & No BW > 500MHz \\
\hline 2 & Half Ground & $\begin{array}{l}8.475 \mathrm{GHz}-10.973 \mathrm{GHz} \\
(\mathrm{BW}=2498 \mathrm{MHz}) \\
13.04 \mathrm{GHz}-13.888 \mathrm{GHz} \\
(\mathrm{BW}=848 \mathrm{MHz}) \\
16.934 \mathrm{GHz}-17.66 \mathrm{GHz} \\
(\mathrm{BW}=726 \mathrm{MHz})\end{array}$ \\
\hline 3 & $\begin{array}{l}\text { Proposed MM } \\
\text { WB antenna }\end{array}$ & $\begin{array}{l}8.728 \mathrm{GHz}-10.357 \mathrm{GHz} \\
(\mathrm{BW}=1629 \mathrm{MHz}) \\
12.777 \mathrm{GHz}-15.702 \mathrm{GHz} \\
(\mathrm{BW}=2925 \mathrm{MHz})\end{array}$ \\
\hline 4 & $\begin{array}{l}\text { Feed line } 0.05 \mathrm{~cm} \\
\text { variation at } \mathrm{MM} \\
\text { side }\end{array}$ & $\begin{array}{l}8.546 \mathrm{GHz}-10.269 \mathrm{GHz} \\
(\mathrm{BW}=1705 \mathrm{MHz}) \\
12.799 \mathrm{GHz}-1.588 \mathrm{GHz} \\
(\mathrm{BW}=759 \mathrm{MHz}) \\
13.69 \mathrm{GHz}-14.515 \mathrm{GHz} \\
(\mathrm{BW}=825 \mathrm{MHz}) \\
17.265 \mathrm{GHz}-18.408 \mathrm{GHz} \\
(\mathrm{BW}=1143 \mathrm{MHz})\end{array}$ \\
\hline 5 & $\begin{array}{l}\text { Feed line } 0.1 \mathrm{~cm} \\
\text { variation at } \mathrm{MM} \\
\text { side }\end{array}$ & $\begin{array}{l}8.685 \mathrm{GHz}-10.302 \mathrm{GHz} \\
(\mathrm{BW}=1617 \mathrm{MHz}) \\
11.765 \mathrm{GHz}-13.789 \mathrm{GHz} \\
(\mathrm{BW}=2024 \mathrm{MHz})\end{array}$ \\
\hline 6 & $\begin{array}{l}\text { Feed line } 0.15 \mathrm{~cm} \\
\text { variation at } \mathrm{MM} \\
\text { side }\end{array}$ & $\begin{array}{l}8.464 \mathrm{GHz}-9.719 \mathrm{GHz} \\
(\mathrm{BW}=1255 \mathrm{MHz}) \\
12.007 \mathrm{GHz}-13.679 \mathrm{GHz}\end{array}$ \\
\hline
\end{tabular}




\begin{tabular}{|c|l|l|}
\cline { 2 - 3 } & & $(\mathrm{BW}=1672 \mathrm{MHz})$ \\
\hline \multirow{4}{*}{7} & Feed line 0.05cm & $8.795 \mathrm{GHz}-9.994 \mathrm{GHz}$ \\
& variation at Port & $(\mathrm{BW}=1199 \mathrm{MHz})$ \\
& side & $9.994 \mathrm{GHz}-11.138 \mathrm{GHz}$ \\
& & $(\mathrm{BW}=1144 \mathrm{MHz})$ \\
& & $12.755 \mathrm{GHz}-14.746 \mathrm{GHz}$ \\
& & $(\mathrm{BW}=1991 \mathrm{MHz})$ \\
\hline \multirow{5}{*}{8} & Feed line 0.1cm & $8.696 \mathrm{GHz}-10.862 \mathrm{GHz}$ \\
& variation at Port & $(\mathrm{BW}=2166 \mathrm{MHz})$ \\
& side & $13.624 \mathrm{GHz}-19.267 \mathrm{GHz}$ \\
& & $(\mathrm{BW}=5463 \mathrm{MHz})$ \\
\hline \multirow{5}{*}{9} & Feed line $0.15 \mathrm{~cm}$ & $8.982 \mathrm{GHz}-11.424 \mathrm{GHz}$ \\
& variation at Port & $(\mathrm{BW}=2442 \mathrm{MHz})$ \\
& side & $13.944 \mathrm{GHz}-15.021 \mathrm{GHz}$ \\
& & $(\mathrm{BW}=1077 \mathrm{MHz})$ \\
& & $15.56 \mathrm{GHz}-16.208 \mathrm{GHz}$ \\
& & $(\mathrm{BW}=648 \mathrm{MHz})$ \\
& & $16.252 \mathrm{GHz}-17.009 \mathrm{GHz}$ \\
& & $(\mathrm{BW}=757 \mathrm{MHz})$ \\
\hline
\end{tabular}

\section{Conclusion}

The proposed Metamaterial based wideband antenna has been analyzed and it exhibits multi band notch characteristics. The frequency ranges from $5 \mathrm{GHz}$ to $7.5 \mathrm{GHz}$ always avoided. And the other frequency bands can be notched by varying strip line as presented in the result section. The VSWR curve also exhibits good range around or less than the 2. The unit cell of MM exhibits the electromagnetic resonance which is very much compatible with the frequency bands obtained for the proposed wideband antenna. The proposed antenna has multiband notch characteristics with improved performance.

\section{References}

[1]. Lin, C.-C. and H.-R. C. Lin, "A 3-12 GHz UWB planar triangular monopole antenna withridged ground-plane," Progress In Electromagnetic Research, Vol. 83, $307\{321,2008$.

[2]. 2. Li, X., L. Yang, S.-X. Gong, and Y.-J. Yang, "Ultra-wideband monopole antenna with four-Band-notched characteristics," Progress In Electromagnetics Research Letters, Vol. 6, 27-34, 2009.

[3]. Chen, Z. N., X. H.Wu, H. F. Li, N. Yang, and M. Y. W. Chia, "Considerations for source pulses and antennas in UWB radio systems," IEEE Trans. Antennas Propag., Vol. 52, $1739\{1748$,Jul. 2004.

[4]. F. Zhu, S. Gao, A. T. S. Ho, C. H. See,R. A. Abd-Alhameed, J. Li, and J. Xu," DESIGN AND ANALYSIS OF PLANAR ULTRAWIDEB-AND ANTENNA WITH DUAL BAND-NOTCHED FUNCTION", Progress In
Electromagnetics Research, Vol. 127, 523-536, 2012.

[5]. Chen, Z. N., M. J. Ammann, X. M. Qing, X. H. Wu, T. S. P. See, and A. Cai, \Planar antennas," IEEE Microw. Mag., Vol. 7, No. 6,63-73, 2006.

[6]. Abbosh, A. M., M. E. Bialkowski, J. Mazierska, and M. V. Jacob,"A planar UWB antenna with signal rejection capability in the4-6 GHz band," IEEE Microw. Wireless Compon. Lett., Vol. 16,No. 5, 278-280, 2006.

[7]. Bialkowski, M. E. and A. M. Abbosh, "Design of UWB planarantenna with improved cut-o® at the out of band frequencies, "IEEE Antennas Wireless Propag. Lett., Vol. 7, 408-410, 2008.

[8]. Chung, K., J. Kim, and J. Choi, "Wideband microstrip-fedmonopople antenna having frequency band-notch function," IEEEMicrow. Wireless Compon. Lett., Vol. 15, No. 11, 766768, 2005.

[9]. Lui, W. J., C. H. Cheng, and H. B. Zhu, "Improved frequencynotched ultra-wideband slot antenna using square ring resonator,"IEEE Trans. Antennas Propag., Vol. 55, No. 9, 2445-2450, 2007.

[10]. Chang, T. N. and M. C. Wu, "Bandnotched design for UWBapplications," IEEE Antennas Wireless Propag. Lett., Vol. 7, 636640, 2008.

[11]. Abbosh, A. M. and M. E. Bialkowski, "Design of UWB planarband-notched antenna using parasitic elements," IEEE Trans.Antennas Propag., Vol. 57, No. 3, 796799, 2009.

[12]. Mohammad Tariqul Islam, Md. Moinul Islam, Md. Samsuzzaman,Mohammad Rashed Iqbal Faruque and Norbahiah Misran "A Negative Index Metamaterial-Inspired UWB Antenna withan Integration of Complementary SRR and CLS Unit Cellsfor Microwave Imaging Sensor Applications", Sensors 2015, 15, 11601-11627; doi:10.3390/s150511601.

Dr. P Siddaiah obtained B.Tech degree in Electronics and communication Engineering from JNTUA College of engineering, Andhra Pradesh, India in 1988. He received his M.Tech degree from SV University Tirupathi, Andhra Pradesh, India. He did his Ph.D program in JNTU Hyderabad, Andhra Pradesh, India. He is the Chief Investigator for several outstanding Projects sponsored by Defence 
Organizations, AICTE, UGC\& ISRO. He is currently working as Professor \& PRINCIPAL, Department of ECE in University College of Engineering and Technology, Acharya Nagarjuna University, Guntur, India. He has taught a wide variety of courses for UG \& PG students and guided several projects. Several members successfully completed their Ph.D under his guidance. Several members pursuing their Ph.D degree. He has published several papers in National \& International Journals \& Conferences. He is the life member of FIETE, IE \& MISTE.

KodaliRaniRudrama obtained her B.Tech degree in Electronics and communication Engineering from Acharya Nagarjuna Univty, Guntur, India in 1992. She received her M.Tech degree from J N T U Hyderabad, Andhra Pradesh, India in 2007. She is presently pursuing Ph.D degree in Electronics and communication Engineering in the field Microstrip patch Antennas from JNTUAnantapur,Anantapur, India.She is the life member of IETE. 